\title{
HABITAR EL CASCO ANTIGUO
}

Editorial

La parte de la ciudad con más años de historia, el casco antiguo, vuelve a requerir una mirada disciplinar intencionada, focalizada sobre un aspecto esencial de la ciudad, que es el de residir o vivir habitualmente.

En este número QRU, Ciutat Vella se convierte en objeto de atención. Un caso singular por su reciente y significativa transformación, con una asignatura pendiente, conservar y recuperar sus capacidades para acoger a sus residentes.

P. Serra nos acerca a los orígenes de la regeneración urbana de Ciutat Vella, proceso en el que reconoce a la vivienda como instrumento clave para el mantenimiento de la vitalidad urbana. Sin embargo, la mejora indiscutible y el impacto positivo de la transformación, no siempre se corresponden con la mejora en la residencia.

Los fenómenos contemporáneos de la conversión del casco antiguo en centro comercial y lugar turístico, presentados por P. Ponsatí y C. Pérez y J. Sabaté, ponen en evidencia la pérdida de lo cotidiano y de proximidad. La actividad comercial y cultural como atractivo de visitantes; el patrimonio y los monumentos como atractivo de turistas, distorsionan el espacio habitable, encarecen los precios y fomentan la actividad temporal, más propia de un parque temático que de una ciudad vivida. $\mathrm{Al}$ mercado ya no se va a comprar, se va a mirar. La ciudad no se vive, se visita.

P. Jiménez, se pregunta si no habría que indagar más allá de la rehabilitación física, reinventar el espacio histórico, buscar nuevas relaciones y crear un nuevo contenedor social que facilite la vida cotidiana pública y privada.

Lo que significa habitar en Ciutat Vella, nos lo explican algunos de sus habitantes, con su testimonio de lo cotidiano. Nos dicen que la belleza es relativa, que los conflictos empiezan no por las diferencias sino por la indiferencia, que la ciudad limpia no lo es todo y que los turistas no merecen tanto privilegio.

P. Feu, indaga sobre los instrumentos para garantizar, no solo el acceso a la vivienda, sino la posibilidad de poder disfrutarla en condiciones adecuadas de habitabilidad. Explica que más allá de las mejoras de la vivienda y del espacio público existen instrumentos que se deben preparar y fortalecer para conservar a los habitantes de la ciudad con necesidad y voluntad de arraigo. 


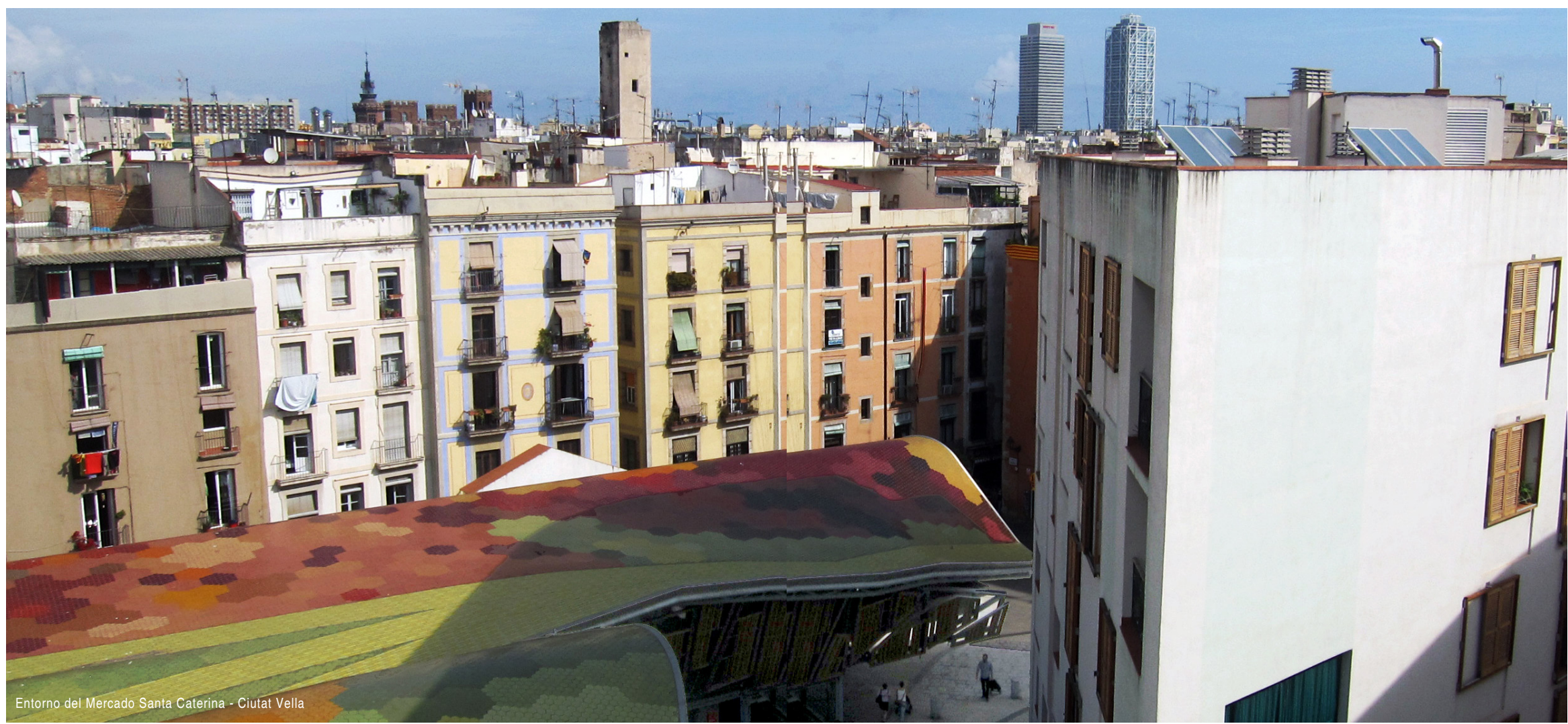

F. Peremiquel invita a pensar en nuevas posibilidades para el casco antiguo, en la habitabilidad de la vivienda, pero también la de la calle, y, sobre todo la belleza de la ciudad, que debería radicar en la posibilidad de ser un espacio sano, eficiente, equitativo, amable, habitable y habitado.

A. Ordoñez pone de manifiesto la necesidad de conservar el uso residencial en los centros históricos para dar un futuro a la ciudad del pasado, que solo siendo habitada puede sobrevivir. Los valores implícitos de estos lugares han de reconocerse de nuevo, para lograr un equilibrio entre la ciudad antigua para ver y la de habitar.

Tres reseñas de libros nos ponen en contexto sobre la mirada disciplinar contemporánea a estos territorios.

P. Font nos introduce a la publicación coordinada por J. Busquets, La Ciutat Vella de Barcelona: un passat amb futur, que nos explica el casco antiguo como un lugar de gran consistencia, pero desigual y heterogéneo.
La reseña de J. Fortuny sobre el libro Venezia è una città. Come è stata costruita e come vive, nos invita a poner en el contexto global la importancia de la discusión sobre el valor del casco antiguo contemporáneo. Nos habla de un texto que destaca a una Venecia que se ha forjado tan particularmente a partir del intenso uso cotidiano; una ciudad que a día de hoy "conserva" la parte física de esa singularidad pero que ha perdido a sus habitantes.

Finalmente, E. Mangada nos pone en contexto para introducirnos al libro La Berlín de Piedra. Historia de la Mayor Ciudad de Caserones de Alquiler, un texto de gran importancia en la cultura urbanística y que ha sido editado por primera vez en castellano.

Desde el punto de vista de la Arquitectura y el Urbanismo la discusión sobre el Centro Histórico se ha centrado alrededor de la permanencia y la transformación físicas. Este volumen de QRU intenta poner sobre la mesa temas que amplíen el enfoque sobre este lugar de la ciudad contemporánea.

Barcelona, julio de 2017 